\title{
Polacy w historii spawania
}

\section{Poles in the history of welding}

\section{Streszczenie}

W artykule zaprezentowano sylwetki inżynierów i badaczy, którzy mieli największy wpływ na rozwój spawalnictwa w Polsce w okresie międzywojennym. Przedstawiono ich biografie, w tym największe osiągnięcia zawodowe.

Słowa kluczowe: spawanie; historia; Polacy

\section{Abstract}

The article presents the profiles of engineers and researchers, who have had the greatest impact on the development of welding in Poland in the interwar period. They present their biographies, including the largest professional achievements.

Keywords: welding; history; Poles

\section{Wstęp}

W Polsce, podobnie jak w całej Europie, spawalnictwo zaczęło się rozwijać na przełomie XIX i XX wieku. Odkrycia w dziedzinie chemii i fizyki pozwoliły na stosowanie nieznanych wcześniej źródeł ciepła i opracowanie nowych technik i technologii łączenia metali. Znaczący wkład w rozwój nowych metod wnieśli polscy uczeni i inżynierowie. Sylwetki tych, którzy mieli największy wpływ na propagowanie i wdrażanie technik spawalniczych w Polsce zostały przedstawione artykule.

Dwie najistotniejsze metody spawania, tj. spawanie elektryczne łukowe i spawanie acetylenowo-tlenowe powstały mniej więcej w tym samym czasie, tzn. pod koniec dziewiętnastego wieku. Już w 1899 r. w Polsce rozpoczęto próby spawania łukowego, wykorzystując metodę opatentowaną przez Stanisława Olszewskiego.

Stanisław Olszewski był pionierem spawania łukowego, jednak przez lata nie doceniano jego wkładu w rozwój tej metody łączenia. Wspólnie z Rosjaninem Nikołajem Benardosem opatentował metodę spawania elektrodą węglową, która dała początek obecnie stosowanym metodom.

Stanisław Olszewski urodził się w War-

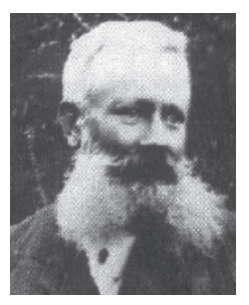
szawie 6.I.1852 r. Studia rozpoczął w Szkole Głównej Warszawskiej na wydziale matematyczno-fizycznym. Po zamknięciu uczelni przez zaborcę, w 1869 r., przerwał naukę i dwa lata później zapisał się na Wydział Górniczy na Uniwersytecie w Liége, gdzie w 1874 r. otrzymał dyplom inżyniera mechanika [1].

Po powrocie do kraju rozpoczął pracę w Zakładach Lilpop, Rau i Loewenstein, a po ślubie w 1876 r. wyjechał jako przedstawiciel generalny firmy do St. Petersburga. Po kilku latach S. Olszewski został sekretarzem generalnym trzech największych syndykatów metalowych w Rosji: wagonowego, szynowego i kolejowego [2]. W Petersburgu S. Olszewski otworzył również własne biuro techniczne i prawdopodobnie dzięki działalności biura S. Olszewski nawiązał współpracę z N. Benardosem. W 1885 r. wspólnie z N. Benardosem, uzyskał patent francuski na sposób łukowego spawania metali (rys. 1) [3], a w kolejnych latach patenty w Belgii, Anglii, Niemczech, Szwecji, Rosji, Hiszpanii, Austro-Węgrzech, USA i Danii [4].

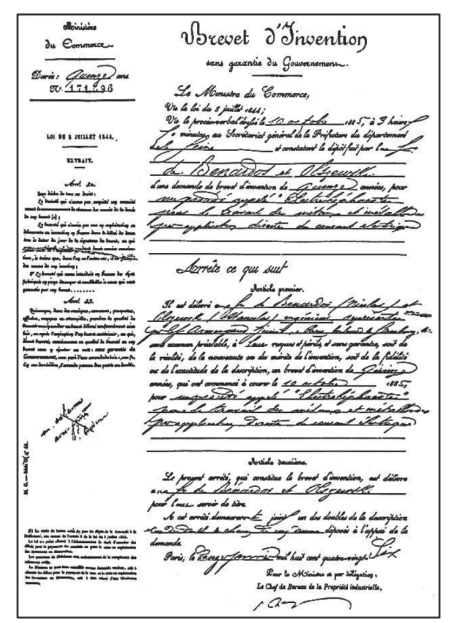

Rys. 1. Pierwszy patent Benardosa -Olszewskiego na spawanie łukowe [3] (patent nr 171596 z 10 października 1885 r.)

Fig. 1. The first patent of Benardos -Olszewski for arc welding

W opisie patentowym są przedstawione trzy wersje sposobu zamontowania i przemieszczania elektrody węglowej w trakcie procesu spawania. W pierwszej wersji, elektroda była zamontowana w prostym drewnianym uchwycie ręcznym. Można ją było przesuwać poosiowo w zacisku lub przechylać względem uchwytu, dzięki zastosowaniu przegubu

Dr inż. Anna Pocica - Politechnika Opolska

Autor korespondencyjny/Corresponding author. a.pocica@po.opole.pl 
walcowego. W drugim przypadku, zastosowano również drewniany uchwyt, stanowiący jednocześnie suport. Dźwignia (G') umożliwiała regulację odległości elektrody od miejsca spawania. Naciśnięcie dźwigni w kierunku uchwytu powodowało zbliżenie elektrody do spawanej powierzchni, a pod działaniem sprężyny, umieszczonej między dźwignią a uchwytem, następowało odsunięcie elektrody. Przewód prądowy był przyłączony zaciskiem (B) do pręta, stykającego się z nastawną końcówką przyrządu, składającą się z zacisku przesuwnego, przegubu walcowego i zacisku elektrody. Stolik r - r', wykonany z płyt metalowych, był podłączony przewodem do ujemnego bieguna źródła prądu, a elektroda do bieguna dodatniego. W trzeciej wersji, suport był przesuwany na rolkach po uzębionych szynach podstawy, co powodowało skokowy przesuw elektrody [3].
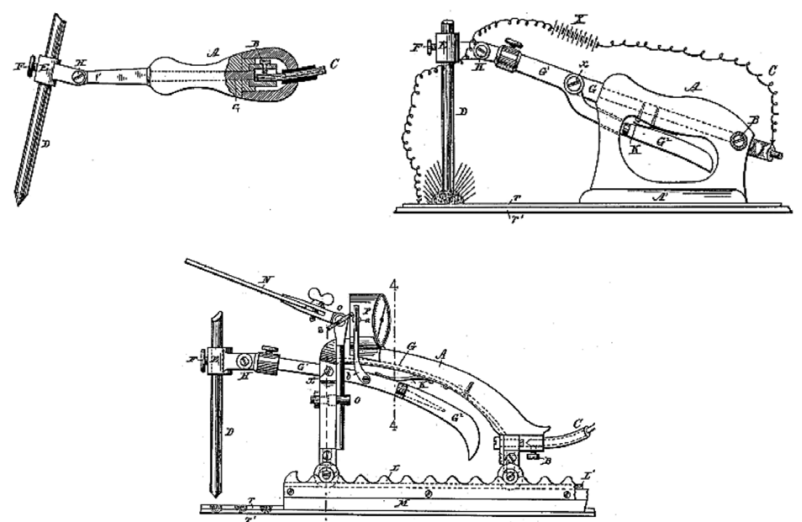

Rys. 2. Patent Benardosa-Olszewskiego - wersje zamontowania elektrody [3]

Fig. 2. Benardos - Olszewski patent - versions of mounted electrodes [3]

Zapewne dzięki Olszewskiemu firma Lilpop, Rau i Loewenstein, jako pierwsza w Polsce wprowadziła spawanie łukiem elektrycznym [5]. Stanisław Olszewski zmarł 15.VII.1898 r. w Giessen, a pięć dni później został pochowany w rodzinnym grobowcu na Cmentarzu Powązkowskim w Warszawie [4].

Opracowane na przełomie wieków metody spawania pozwoliły na znaczny rozwój rzemiosła i przemysłu. Unowocześnienie przemysłu było szczególnie istotne na ziemiach polskich, zacofanych przez działania zaborców i zniszczonych w wyniku działań wojennych. Polska dzięki wprowadzeniu spawania w wielu dziedzinach osiągnęła światowy poziom. Przyczynił się do tego, bez wątpienia, prof. Stefan Bryła, najwybitniejszy spawalnik okresu międzywojennego.

Stefan Bryła urodził się 17.VIII. $1886 \mathrm{r}$. w Krakowie. W 1908 r. ukończył studia na Wydziale Inżynierii Lądowej Politechniki Lwowskiej, rok później się doktoryzował, w 1910 r. habilitował ze statyki budowli i rozpoczął wykłady $z$ encyklopedii nauk inżynierskich. W 1910 r. wyjechał na dwuletnie studia - najpierw do Berlina, a następ-

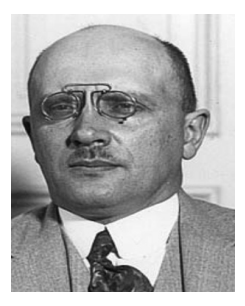
nie do Paryża i Londynu [6]. Z Londynu, w 1912 r., pojechał do Stanów Zjednoczonych, gdzie brał udział w budowie najwyższego w tamtym czasie budynku, 250 metrowego Woolworth Building w Nowym Jorku.

W 1918 r. S. Bryła wrócił do kraju i w 1919 r. rozpoczął pracę w Ministerstwie Robót Publicznych Po wojnie 1920 r. został profesorem zwyczajnym budowy mostów w Politechnice Lwowskiej, a w 1934 r. został powołany na stanowisko profesora na Wydziale Architektury Politechniki Warszawskiej. Katedrą Architektury kierował aż do tragicznej śmierci w 1943 r. [7].

Zainteresowania naukowe prof. S. Bryły dotyczyły stalowych konstrukcji budowlanych i mostowych, a wprowadzenie do nich spawania było jego największą zasługą dla nauki polskiej. Jego działalność obejmowała prace teoretyczne, badania połączeń i elementów spawanych, tworzenie rozwiązań konstrukcyjnych, charakterystycznych dla tej metody, opracowywanie konstrukcji spawanych, opisy zrealizowanych obiektów i stałą popularyzację spawania [8].

Wiele konstrukcji inżynierskich w okresie międzywojennym zostało opracowanych przez prof. Bryłę. Najważniejszym jego projektem był pierwszy na świecie most spawany na Słudwi pod Łowiczem (rys. 3) [9]. Montaż mostu ukończono w grudniu 1928 r., a w sierpniu 1929 roku oddano most do użytku.

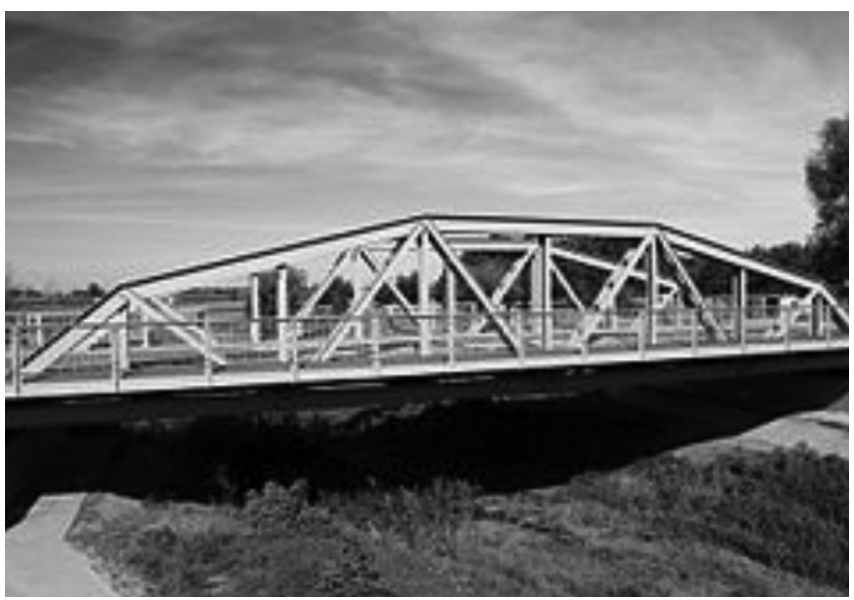

Rys. 3. Pierwszy most spawany na Słudwi pod Łowiczem. [9] Fig. 3. The first welded bridge on Słudwia near Łowicz

W związku z budową tego mostu prof. S, Bryła opracował pierwsze w świecie przepisy spawania konstrukcji stalowych. Przepisy te stosowano od 1931 r. w Niemczech, a od 1932 r. w Szwajcarii [10].

Dwie pierwsze w Europie spawane konstrukcje budowlane również zaprojektował prof. S. Bryła. Był to gmach PKO w Warszawie (rys.4a) [11] i budynek Towarzystwa „Prudential" (rys. 4b) [12].

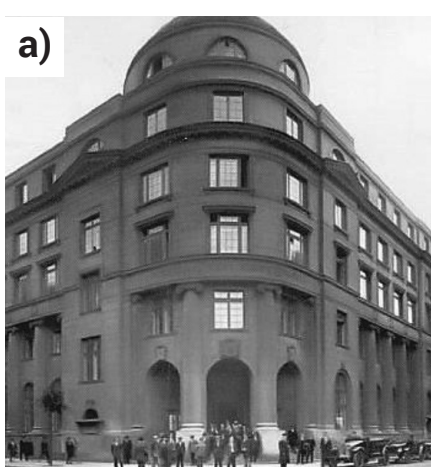

b)

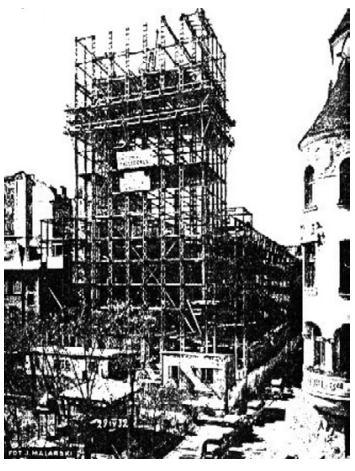

Rys. 4. Gmach PKO w Warszawie (a) [11], gmach „Prudential House" - najwyższy budynek w przedwojennej Polsce (b) [12] Fig. 4. PKO building in Warsaw (a) [11]. Prudential House - the tallest building in pre-war Poland (b) [12]

W czasie okupacji S. Bryła nie zaprzestał intensywnej działalności. Prowadził tajne nauczanie na Wydziale Architektury, organizował działalność Polskiego Związku Inżynierów Budowlanych, kierował Biurem Wojskowym Przemysłu, a także pracował nad utworzeniem Tajnej Organizacji Inżynierskiej. W 1942 r. został aresztowany, zwolniony po kilku tygodniach, został ponownie aresztowany w listopadzie 1943r. Po dwóch tygodniach 3.XII. 1943 r. został rozstrzelany w egzekucji ulicznej w Warszawie [6]. 
Rozwój spawalnictwa w Polsce nie byłby możliwy w oparciu o zagraniczne materiały i urządzenia. Produkcję elektrod wprowadził i rozwijał prof. Józef Pilarczyk, a głównym producentem maszyn i urządzeń byłą firma "Perun" kierowana przez inż. Alfreda Sznerra.

Józef Pilarczyk urodził się 21.III.1909 r. w Hermanowicach na Śląsku. W 1933 r. pracując w hucie Pokój w Nowym Bytomiu (obecnie Ruda Śl.) uzyskał dyplom inżyniera metalurga w AGH w Krakowie. Prawdopodobnie podczas stażu w hucie zetknął się po raz pierwszy z produkcją elektrod otulonych [13]. W 1934 r. J. Pilarczyk zo-

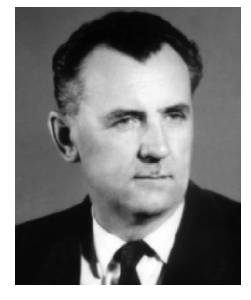
stał przeniesiony do organizowanego w hucie "Baildon" w Katowicach zakładu produkcji elektrod. Początkowo w hucie "Baildon” produkowano 5 gatunków elektrod otulonych. Po podpisaniu umowy licencyjnej z firmą Agil Chemie-Werke wytwarzano 12, a w 1938 r. 15 gatunków elektrod otulonych, w tym 9 według własnych opracowań [14].

Od 1935 r. rozpoczęła się działalność dydaktyczna J. Pilarczyka. W kwietniu i maju prowadził zajęcia na pierwszych w Łodzi kursach spawania elektrycznego, zorganizowanych przez Towarzystwo Kursów Technicznych i firmę „Elektrobudowa", a od 1937 r. wykładał na kursach, które odbywały się w spawalni huty „Baildon” [13].

Po wybuchu wojny J. Pilarczyk pracował w Stalowej Woli, następnie w Bytomiu, a od 1942 r. w Krakowie. Po wyzwoleniu Krakowa, został skierowany przez władze polskie do Katowic, gdzie początkowo pracował w hucie „Baildon”, a następnie przyjął stanowisko zastępcy dyrektora powstającego Instytutu Spawalnictwa, Po śmierci dyrektora B. Szuppa, w 1958 r. został dyrektorem Instytutu i funkcję tę sprawował do 1967 r. [15].

Równocześnie z pracą w Instytucie prowadził wykłady ze spawalnictwa w Politechnice Śląskiej w Gliwicach. W trakcie długoletniej pracy wykształcił 650 inżynierów spawalników i promował kilkunastu doktorów. Bardzo bogata bibliografia Profesora obejmuje kilka podręczników, ponad 20 artykułów, 2 skrypty i szereg referatów na krajowych i zagranicznych konferencjach naukowych, a także kilka rozdziałów w każdym z dwóch wydań „Poradnika Spawalniczego” [13].

Prof. Józef Pilarczyk zmarł 5.XI.1978 r. w Katowicach i został pochowany na cmentarzu ewangelickim w Ustroniu [13].

Alfred Sznerr urodził się 21.XII.1883 r. w Turku koło Kalisza. W 1902 r. ukończył szkołę realną i rok później rozpoczął studia na uniwersytecie w Gandawie. W 1905 r. przeniósł się do Szwajcarii i studiował chemię na Wydziale Przyrodniczym Uniwersytetu we Fryburgu. Po 5 latach nauki, w 1910 r. zakończył studia doktoratem, w którym określił własności skroplonych gazów [16].

Po studiach, jako pełnomocnik francuskiej firmy L`Air Liquide, założył w Warszawie biuro sprzedaży importowanych gazów oraz urządzeń do spawania i cięcia. W związku ze znacznym zapotrzebowaniem na gazy, w grudniu $1910 \mathrm{r}$. została uruchomiona produkcja tlenu w firmie "Perun” Warszawie [17]. W 1913 r. z inicjatywy A. Sznerra nastąpiło połączenie biura przedstawicielskiego L`Air Liquide oraz Spólki Akcyjnej „Perun” i pod nazwą Francuskie Towarzystwo Akcyjne „Perun” rozpoczęto wytwarzanie sprzętu i materiałów spawalniczych. W czasie I wojny światowej przerwano produkcję i wznowiono ją zaraz po zakończeniu działań wojennych. W 1919 r. A. Sznerr został dyrektorem „Peruna” i pełnił tę funkcję do 1944 r. [16]. W fabryce i jej oddziałach produkowano: gazy techniczne - tlen i acetylen, bezpieczniki wodne, wytwornice acetylenu, reduktory, palniki, urządzenia do cięcia, transformatory do spawania łukiem elektrycznym, a także spoiwa do spawania gazowego i elektrycznego [18]. Pod kierownictwem A. Sznerra firma intensywnie się rozwijała i w latach 1918-1939 powstały jej filie w Bydgoszczy, Lwowie, Trzebini, Dąbrówce Małej i Skarżysku [16].

Z inicjatywy A. Sznerra, w 1928 r., powstał Związek Polskiego Przemysłu Acetylenowego i Tlenowego, przemianowany na Stowarzyszenie dla Rozwoju Spawania i Ciecia Metali w Polsce [19].

A. Sznerr był niestrudzonym propagatorem spawalnictwa. Prowadził wykłady w Państwowej Wyższej Szkole Budowy Maszyn i Elektryczności im. H. Wawelberga i S. Rotwanda w Warszawie, wykładał też na licznych kursach organizowanych przez Stowarzyszenie. W czasie okupacji, wraz z innymi specjalistami, opracowywał plany odbudowy przemysłu po wojnie. Po Powstaniu Warszawskim znalazł się najpierw w Podkowie Leśnej, a następnie w Krakowie, gdzie zmarł 30.VII.1945 r. [16].

Propagowaniem spawalnictwa, podobnie jak inż. A. Sznerr, zajmował się prof. Zygmunt Dobrowolski.

Zygmunt Dobrowolski urodził się 13.V.1891 r. w Warszawie. W 1923 r. ukończył studia w Lwowskiej Szkole Politechnicznej na kierunku budowy parowozów. W trakcie studiów pracował w warsztatach kolejowych PKP i tam po raz pierwszy zetknął się z techniką spawalniczą. Po studiach Z. Dobrowolski wrócił do Warszawy i został zatrudniony w nowo powstałej wytwórni parowozów, na stanowisku inżyniera ruchu.

Szerokie zainteresowania Z. Dobrowolskiego i dobra znajomość spawalnictwa zostały docenione i gdy w 1928 r., z inicjatywy Stowarzyszenia dla Rozwoju Spawania i Cięcia Metali, powstał miesięcznik "Spawanie i Cięcie Matali”, zaproponowano mu stanowisko dyrektora i redaktora czasopisma. Po roku został zatrudniony w Towarzystwie Akcyjnym Perun na stanowisku głównego inżyniera i kierownika wydziału spawania. Funkcję tę pełnił do wybuchu wojny, będąc jednocześnie redaktorem miesięcznika [20].

Równocześnie z wydawaniem czasopisma Z. Dobrowolski opracowywał co roku „Kalendarze Peruna”, dostarczane bezpłatnie klientom (30 000 w 1938 r.) . Kalendarze, oprócz wiadomości o wyrobach firmy, zawierały informacje naukowo-techniczne o różnych metodach spawania, zgrzewania i cięcia [20]. Z jego inicjatywy w 1938 r. powstało kolejne czasopismo spawalnicze - dwumiesięcznik "Spawacz", przeznaczony dla praktyków [21].

Po klęsce wrześniowej wyjechał do Paryża i został kierownikiem ośrodka dokumentacji Francuskiego Instytutu Spawania, mającego najstarszą na świecie bibliotekę spawalniczą.

Po zakończeniu wojny, w 1945 r., Z. Dobrowolski powrócił do Warszawy. Początkowo zajmował się organizowaniem Zjednoczenia Przemysłu Gazów Technicznych, następnie został rzeczoznawcą w Państwowej Komisji Planowania Gospodarczego, a w latach 1949-1950 organizował Instytut Dokumentacji Naukowo-Technicznej. W kwietniu 1951 r. otrzymał tytuł profesora nadzwyczajnego i został kierownikiem Katedry Spawalnictwa na Wydziale Mechanicznym Technologicznym Politechniki Warszawskiej [20].

Po reaktywacji miesięcznika spawalniczego, pod nową nazwą „Przegląd Spawalnictwa” został jego redaktorem naczelnym. Prof. Z. Dobrowolski zmarł w Warszawie 12.VIII.1981 r. i został pochowany na Cmentarzu Powązkowskim [20].

Wspominając spawalników, którzy najbardziej przyczynili się do rozwoju spawalnictwa, nie można zapomnieć o inż. Piotrze Tułaczu.

Dzisiejszym spawalnikom to nazwisko niewiele powie, ale jemu współcześni uważali go za mistrza, człowieka którego należało i warto było naśladować. Inżynier Piotr Tułacz był wybitnym spawalnikiem, konstruktorem lotniczym, autorem 
trzech książek, wielu artykułów naukowych, referatów, odczytów. Publikował, uzyskiwał patenty, rozwijał polskie spawalnictwo, by dobrze służyło rozwojowi młodego państwa.

Piotr Teodor Tułacz urodził się $11 \mathrm{li}$ stopada 1892 roku w Nadwórnej, w województwie stanisławowskim. W 1920 r. ukończył studia w Paryżu i rozpoczął pracę w Parku (warsztatach) Szkoły Lotniczej w Bydgoszczy. Po dwóch latach, 20.10.1922 r. został przeniesiony na równorzędne stanowisko do 3 Pułku Lotniczego w Poznaniu na Ławicy [22]. Na po-

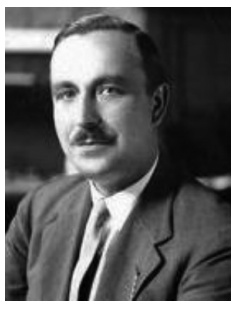
czątku 1923 r. P. Tułacz zaprojektował i zbudował szybowiec M-1, a trzy lata później został głównym projektantem samolotu SP-1, na wskroś nowoczesnego płatowca.

Rok 1927 był przełomowy w działalności Piotra Tułacza. Został dyrektorem Katowickiego Oddziału Związku Polskiego Przemysłu Acetylenowego i Tlenowego i zajął się organizacją ośrodka szkoleniowego spawaczy w Katowicach. Prawdopodobnie już w drugiej połowie 1928 r. inż. Tułacz zainicjował pionierskie w skali światowej prace nad ustaleniem testów psychotechnicznych dla kandydatów na spawaczy.

W marcu 1931 roku złożył w Urzędzie Patentowym dwa wnioski; pierwszy na "Automatyczną wytwornicę acetylenu”, drugi na „Bezpiecznik wodny do aparatów acetylenowych. Oba patenty, o numerach 18523 i 18536, przyznano 31 maja 1933 roku [18].

W 1931 r. inż. P. Tułacz rozpoczął wykłady w Akademii Górniczej w Krakowie. Zajęcia ze studentami prowadził do 1939 r., przy czym od 1937 r. nie pobierał za nie wynagrodzenia. Równocześnie organizował kursy, głównie w Katowicach, Krakowie i Lwowie, zarówno dla spawaczy, jak i inżynierów i techników [22].
Pracę dydaktyczno - organizacyjną łączył z badaniami połączeń spawanych i opracowywaniem nowych technologii. Zaczął interesować się możliwościami zastosowania spawania w kolejnictwie. W 1933 r. zgłosił do opatentowania dwa rozwiązania: na podkładkę z walcowanej stali podpierającą styk szyn z twardej stali i na sposób spawania główek szyn. Patenty, o numerach 21076 i 23824 otrzymał w latach 1935 i 1936 [18]. W 1934 r. zgłosił do opatentowania „spawane złącze szynowe", którego ideę przedstawił na XII Międzynarodowym Kongresie Spawania w Londynie. Za swoją pracę otrzymał srebrny medal Kongresu, co warte jest podkreślenia, bo przyznano jedynie trzy nagrody, z czego dwie przypadły Francuzom [18]. Patent na swoje rozwiązanie otrzymał 20.07.1937 r. [18]. W 1936 r. zgłosił „sposób spawania główek szyn", na co uzyskał patent nr 26918 w 1938 r. [18].

W złączu tym spawano doczołowo płomieniem acetylenowym szynę na całym przekroju, a następnie na miejsce spojenia nasuwano podkładkę o specjalnym kształcie, którą spawano z dwóch stron równocześnie, u nasady szyjki [23].

W 1939 r. inż. P. Tułacz został zmobilizowany i po klęsce wrześniowej, przez Rumunię przedostał się do Francji, gdzie wiosną 1940 r. został skierowany do pracy w warsztacie wytwórni samolotów SNCA-SE w Argenteuil, lecz prawdopodobnie się tam nie zgłosił. I w tym miejscu ślad się urywa. Wieloletnie poszukiwanie informacji nie dało żadnych rezultatów. Możliwe, że z Anglii wyjechał do USA lub Kanady, ale nie potwierdzają tego organizacje polonijne. Według Czerwonego Krzyża był w Lizbonie i stamtąd wyjechał do Anglii lub USA, ale te informacje również nie zostały potwierdzone [22].

Lata dwudzieste i trzydzieste XX wieku to okres największego rozwoju spawalnictwa w Polsce. Było to możliwe dzięki działalności wielu, czasami bezimiennych, pasjonatów tej metody, o wielu z nich zapomniano i trzeba o nich przypomnieć.

\section{Literatura}

[1] Królikowski L.: Kilka nowych szczegółów dotyczących życia i działalności Stanisława Olszewskiego. Przegląd Spawalnictwa, 1989, nr 6 s. okładka II.

[2] Wróblewski A.: Fragetowe łyżeczki. Czytelnik, Warszawa, 1955, s. 226

[3] Memoire descriptf d`un procédé applé Electrohephaeste par N.N. Benardos et Stanislas Olszewski pour le travail des métauxet metalloides par application di recte du courant électrique. Patent nr 171596 z 10 października 1885.

[4] Buczyński L.: W 100 rocznicę wynalezienia procesu łączenia metali za pomocą łuku elektrycznego. Przegląd Spawalnictwa, 1986, nr 1, s. 17-22.

[5] Sprawozdania z posiedzeń stowarzyszeń technicznych. Sekcja Techniczna Warszawska. Przegląd Techniczny, 1899, nr 20, s. 341.

[6] Orłowski B.: Poczet wielkich inżynierów. Wyd. Nasza Księgarnia, Warszawa, 1966, s.115-117.

[7] Nechay J.: Życiorys. Monografia działalności naukowej Stefana Bryły. WNT, Warszawa, 1959, s.13-23.

[8] J.B.: Studium porównawcze spawania acetylenowego i elektrycznego. Spawanie i Cięcie Metali, 1933, nr 8, s. 116-119.

[9] Bryła S.: Most żelazny spawany elektrycznie na rzece Słudwi pod Łowiczem. Spawanie i Cięcie Metali, 1929, nr 11, s. 186-194.

[10] Poniż V.: Dziesięciolecie spawania konstrukcji stalowych w Polsce. Przegląd Techniczny, 1937, nr 13, s. 451-455.

[11] Kołakowski B.: Kilka słów o montażu konstrukcji spawanych gmachu PKO w Warszawie. Przegląd Spawalnictwa, 1952, z.1, s. 10-14.

[12] Bryła S: Najwyższy stalowy budynek szkieletowy w Polsce. Czasopismo Techniczne, 1934, nr 1, s. 6-10.
[13] Lassociński J.:Bolesław Szupp i Józef Pilarczyk: Oni kładli podwaliny Instytutu. Biuletyn Instytutu Spawalnictwa, 1995, nr 4, s. 7-17.

[14] Elektrody Baildon. Wyd. Huta Pokój Śląskie Zakłady Górniczo- Hutnicze S.A. Katowice, 1935, s.34-40.

[15] Jaros J.: Pilarczyk Józef. Słownik biograficzny techników polskich. Wyd. NOT-SIGMA, Warszawa, 1989, t. I, s. 115-116.

[16] Nekanda-Trepka L.: Sznerrr Alfred. Słownik biograficzny techników polskich. Wyd. NOT-SIGMA, Warszawa, 2000, t. XI, s. 155-156.

[17] Przemysł tlenowy w Polsce. Spawanie i Cięcie Metali, 1930, nr1, s. 21-22

[18] Pocica A. : Techniki i technologie spawalnicze na ziemiach polskich do 1939r. Studia i monografie z 418. Politechnika Opolska, Opole 2015.

[19] Lassociński J.: Stowarzyszenie dla Rozwoju Spawania i Cięcia Metali w Polsce. Słownik polskich towarzystw naukowych, t. II, cz.2, Wyd. PAN, Warszawa, 1994, s. 174-178.

[20] Nekanda-Trepka L.: Dobrowolski Zygmunt. Słownik biograficzny techników polskich. Wyd. NOT-SIGMA, Warszawa, 1995, t. VI, s. 31-33.

[21] Po 10 latach. Spawanie i Ciecie Metali, 1938, nr 1, s. 2.

[22] Pocica A., Nowak A.: Inżynier Piotr Teodor Tułacz. Przegląd Spawalnictwa, 2005, nr 6, s. 8-9.

[23] Tułacz P.: Postępy w dziedzinie spawania acetylenowego złącz szynowych. Odczyt wygłoszony na III Międzynarodowym Kongresie Szynowym w Budapeszcie we wrześniu 1935. Spawanie i Cięcie Metali, 1935, nr 12, s. $210-216$. 